\title{
Phytoestrogen Bakuchiol Exhibits In Vitro and In Vivo Anti-breast Cancer Effects by Inducing S Phase Arrest and Apoptosis
}

\author{
Li Li', Xueping Chen², Chi C. Liu', Lai S. Lee³, Cornelia Man'3 and Shuk H. Cheng1* \\ ${ }^{1}$ Department of Biomedical Sciences, City University of Hong Kong, Hong Kong, China, ${ }^{2}$ Vitargent (International) \\ Biotechnology Limited, Hong Kong, China, ${ }^{3}$ Department of Applied Biology and Chemical Technology, Hong Kong \\ Polytechnic University, Hong Kong, China
}

OPEN ACCESS

Edited by:

Agata Copani,

University of Catania, Italy

Reviewed by:

Andy Sunters,

Royal Veterinary College, UK

Nadezhda A. German,

Texas Tech University Health

Sciences Center, USA

${ }^{*}$ Correspondence:

Shuk H. Cheng

bhcheng@cityu.edu.hk

Specialty section:

This article was submitted to

Experimental Pharmacology and Drug

Discovery,

a section of the journal

Frontiers in Pharmacology

Received: 02 March 2016 Accepted: 05 May 2016

Published: 24 May 2016

Citation:

LiL, Chen X, Liu CC, Lee LS, Man C and Cheng SH (2016) Phytoestrogen Bakuchiol Exhibits In Vitro and In Vivo Anti-breast Cancer Effects by Inducing S Phase Arrest and Apoptosis.

Front. Pharmacol. 7:128.

doi: 10.3389/fphar.2016.00128
Phytoestrogen has been proposed as an alternative to hormone replacement therapy, which has been demonstrated to promote a high risk of breast cancer. However, the effect of phytoestrogen on breast cancer development has not been fully understood. Bakuchiol is an active ingredient of a traditional Chinese herbal medicine Fructus Psoraleae, the dried ripe fruit of Psoralea corylifolia L. (Fabaceae). The in vitro and in vivo estrogenic activities and anti-breast cancer effects of bakuchiol have not been wellstudied. We found that bakuchiol induced the GFP expression in transgenic medaka (Oryzias melastigma, Tg, Chg:GFP) dose-dependently $(0-1 \mu \mathrm{g} / \mathrm{ml})$, demonstrating its in vivo estrogenic activity. Low dose of bakuchiol $(1 \mu \mathrm{g} / \mathrm{ml})$ induced the cell proliferation and $\mathrm{ER} \alpha$ expression in MCF-7 cells, which could be blocked by the anti-estrogen ICI 182780, suggesting the in vitro estrogenic activity of bakuchiol. Our data indicated that high doses of bakuchiol (>2 $\mu \mathrm{g} / \mathrm{ml}$ ) inhibited breast cancer cell growth, with a stronger anti-proliferative effect than resveratrol, a widely studied analog of bakuchiol. High doses of bakuchiol $(4,7$, and $10 \mu \mathrm{g} / \mathrm{ml})$ were used for the further in vitro anti-breast cancer studies. Bakuchiol induced ER $\beta$ expression and suppressed ER $\alpha$ expression in MCF-7 cells. It also induced S phase arrest in both MCF-7 and MDA-MB-231 cells, which could be rescued by caffeine. Knock-down of p21 also marginally rescued $S$ phase arrest in MCF-7 cells. The $S$ phase arrest was accompanied by the upregulation of ATM, P-Cdc2 (Tyr15), Myt1, P-Wee1 (Ser642), p21 and Cyclin B1, suggesting that blocking of Cdc2 activation may play an important role in bakuchiol-induced S phase arrest. Furthermore, bakuchiol induced cell apoptosis and disturbed mitochondrial membrane potential in MCF-7 cells. The bakuchiol-induced apoptosis was associated with increased expression of Caspase family and Bcl-2 family proteins, suggesting that bakuchiol may induce apoptosis via intrinsic apoptotic pathway. The in vivo antibreast cancer effect of bakuchiol was further proved in zebrafish (Danio rerio, wild-type AB) xenografts. $0.5 \mu \mathrm{g} / \mathrm{ml}$ of bakuchiol significantly reduced the MCF-7 cell mass in zebrafish xenografts. Overall, these results suggested the potential of using bakuchiol in HRT and breast cancer treatment.

Keywords: bakuchiol, estrogenic activity, $\mathbf{S}$ phase arrest, apoptosis, breast cancer cell, medaka, zebrafish 


\section{INTRODUCTION}

According to the statistics released by the International Agency for Research on Cancer (2013), 1.7 million women were diagnosed with breast cancer, which killed more than 0.5 million women in 2012. The incidence rate and mortality had been increased by 20 and $14 \%$ respectively since 2008 to 2012 . Breast cancer incidence in developed countries of North America and Western Europe is historically higher than in Asian countries, which has been associated to the higher intake of phytoestrogens in the eastern continent (de Kleijn et al., 2001).

Phytoestrogens are a group of plant-derived substances, with an estradiol-like structure or function. The main phytoestrogen groups are lignans, flavonoids, coumestans, and stilbenes. Interest in phytoestrogen has also increased as a result of the concerns about HRT. HRT is widely used to relieve the menopausal symptoms of post-menopausal women. However, it has been demonstrated that estrogen, which is used in HRT, increases the risk of breast cancer development (Key et al., 2001). Thus, women, mainly those with a history of breast cancer, are turning to the use of phytoestrogens, in the belief that they protect them from breast cancer and they are safer than estrogen itself.

Selective estrogen receptor modulators are compounds that selectively interact with ER either as ER agonists or antagonists in different organs. They have been studied in the past decade to treat hormone responsive cancer and menopausal symptoms. Phytoestrogens have been proposed as natural SERMs (Oseni et al., 2008). Lignans are the most major phytoestrogens found in many fiber-rich foods such as cereal brans, fruits and vegetables. They possess weak estrogenic or anti-estrogenic activities (Pianjing et al., 2011). Soy isoflavones, such as genistein and daidzein, are the most widely studied phytoestrogens. These isoflavones have varying estrogenic and anti-carcinogenic activities, and they have been proposed as natural SERMs (Setchell, 2001). There are also many studies on coumestans. Coumestans are found in various beans, alfalfa, and clover sprouts. Many of their biological effects can be attributed to their activation of ER signaling pathway, and the anti-cancer effects of these compounds have been also described in the last decade (Nehybová et al., 2014). Resveratrol, found naturally in grapes and red wine, is the most common stilbene. It has gained considerable attention because of its chemopreventive, anti-oxidative, and anti-inflammatory properties (Patisaul and Jefferson, 2010). Although, there are many in vitro and in vivo data on the role of phytoestrogens in breast cancer treatment, the data needs further research.

Bakuchiol is a meroterpene, which can be found in the traditional Chinese herbal medicine Fructus Psoraleae, the dried

Abbreviations: Chg, choriogenin; DMEM, Dulbecco's modified Eagle medium; DMSO, dimethyl sulfoxide; dph, days of post-hatching; E2, 17 $\beta$-estradiol; EC50, effective concentration 50; ER, estrogen receptor; FBS, fetal bovine serum; GFP, green fluorescent protein; hpf, hours of post-fertilization; HRT, hormone replacement therapy; LC50, lethal concentration 50; PBS, phosphatebuffered saline; PI, propidium iodide; PMSF, phenylmethylsulfonyl fluoride; PTU, phenythiourea; RIPA buffer, radio-immunoprecipitation assay buffer; SERM, selective estrogen receptor modulator.

${ }^{1}$ http://www.iarc.fr/en/media-centre/pr/2013/pdfs/pr223_E.pdf ripe fruit of Psoralea corylifolia L. (Fabaceae). It is shown to have anti-microbial, anti-inflammatory, anti-oxidative, antiosteoporosis, and anti-depression or anti-stress activities (Lim et al., 2009; Choi et al., 2010; Kim et al., 2013; Huang et al., 2014; Mao et al., 2014). The estrogenic activities of bakuchiol were reported in several in vitro models (Xin et al., 2010; Lim et al., 2011; Mao et al., 2014). However, whether bakuchiol displays estrogenic activity in in vivo model is rarely studied (Shou et al., 2007; Lim et al., 2009). We developed transgenic medaka (Oryzias melastigma, Tg, Chg:GFP), in which the liverspecific and estrogen-sensitive choriogenin gene promoter drives GFP expression, in a previous study (Chen et al., 2007). With this transgenic fish, we could screen estrogenic activity of bakuchiol in vivo. The anti-cancer potential of bakuchiol has been reported in very few studies. Bakuchiol inhibits liver cancer cell growth through inducing $S$ phase arrest, caspase 9/3 activaton, p53 and Bax up-regulation, as well as Bcl-2 down-regulation (Chen Z. et al., 2010). It also inhibits human carboxylesterase 2, which is commonly expressed in tumor tissue and involved in the metabolism of endogenous lipids and drugs (Li et al., 2015). To date, limited studies have demonstrated the effect of bakuchiol on breast cancer cell growth (Chen H.L. et al., 2010; Xin et al., 2010). However, the anticancer effect of resveratrol, an analog of bakuchiol, has been extensively reported (Bernhard et al., 2000; Joe et al., 2002; Tyagi et al., 2005; Chen et al., 2013). The mechanisms of the anti-cancer effects of resveratrol, including promoting cell cycle arrest, inducing apoptosis, preventing tumor-derived nitric oxide synthase expression, inhibiting cyclooxygenase activity, and decreasing DNA binding activity of nuclear factor $\kappa \mathrm{B}$, have been well-summarized in a previous review (Carter et al., 2014). However, the mechanisms of how bakuchiol affects breast cancer cell growth and the in vivo anti-breast cancer effects of bakuchiol have not been investigated. It is important to investigate the estrogenic and anti-breast cancer activities of bakuchiol both in vitro and in vivo, and to reveal the underlying mechanisms of these effects.

\section{MATERIALS AND METHODS}

\section{Chemicals and Reagents}

Bakuchiol \{4-[(1E,3S)-3-ethenyl-3,7-dimethylocta-1,6-dienyl] phenol\} (Figure 1) purity $98 \%$ by HPLC, was obtained from

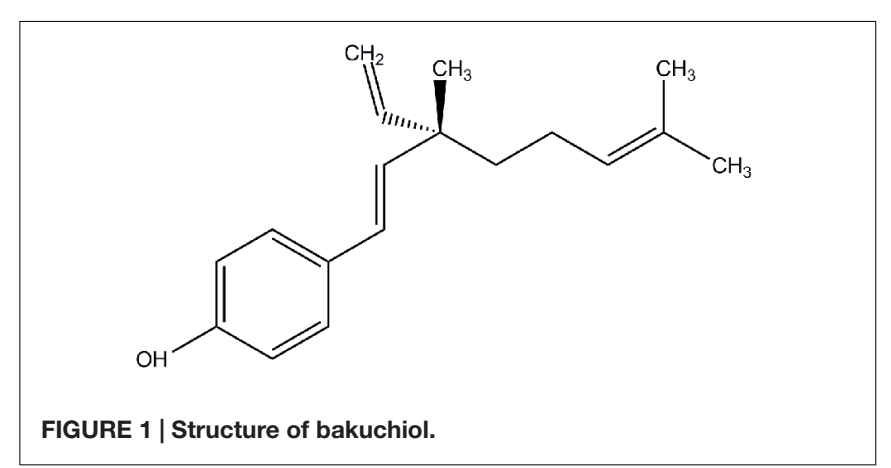


Enzo (Farmingdale, NY, USA). Resveratrol, 17 $\beta$-estradiol (E2), and PTU was purchased from Sigma (St. Louis, MO, USA). ICI 182780 was bought from Abcam (Cambridge, MA, USA). DMEM, FBS, penicillin, streptomycin, PI, JC-1 dye, TRIzol reagent and PBS were purchased from Invitrogen (Carlsbad, CA, USA). FuGENE 6 transfection reagent, MTT, DMSO, caffeine, RNase A, annexin V-FITC/PI apoptosis kit, RQ1 RNase-free DNase, RIPA buffer, PMSF and $\mathrm{Na}_{2} \mathrm{CO}_{3}$ were bought from Promega (Madison, WI, USA). Kapa SYBR FAST qPCR kit was obtained from Kapa Biosystems (Wilmington, MA, USA), and high capacity RNA-to-cDNA master mix came from Applied Biosystems (Carlsbad, CA, USA). ECL Prime Western blotting detection system was obtained from GE Healthcare (Milwaukee, WI, USA). All antibodies were purchased from Cell Signaling Technology (Danvers, MA, USA).

\section{Medaka Fish Exposure}

Larvae within 2 days dph were used for exposure. Twenty larvae were exposed in a $50 \mathrm{~mm}$ glass Petri dish for $24 \mathrm{~h}$. Triplicates were carried out for each concentration and for the solvent control. After exposure, the fish were deposited onto the inner side of Petri dish cover with little water left. The induced GFP expression in the liver was observed under stereomicroscope (model M205 FA, Leica Microsystems, Germany). The images were recorded with the same parameter settings for the same set of exposed samples. Fluorescence intensity was quantified by image analysis software, Metamorph 5.0 (Universal Imaging, Downingtown, PA, USA). To reduce the interference of fish auto-fluorescence, only the fish liver was selected for analysis. The average fluorescence of the liver area was regarded as the GFP signal intensity. All procedures with fish were conducted following the License to Conduct Experiments approved by the Government of the Hong Kong SAR Department of Health [Ref. (21) in DH/HA\&P/8/1/1 Pt.3].

\section{Cell Culture}

Two breast cancer cell lines were used in this study. MCF7 (ATCC: HTB-22) and MDA-MB-231 (ATCC: HTB-26) were purchased from American Type Culture Collection (ATCC, Manassas, VA, USA), The cell lines were routinely maintained in DMEM supplemented with $10 \% \mathrm{FBS}, 0.37 \% \mathrm{Na}_{2} \mathrm{CO}_{3}, 50$ units $/ \mathrm{ml}$ penicillin and $50 \mu \mathrm{g} / \mathrm{ml}$ streptomycin, incubated at $37^{\circ} \mathrm{C}$ in a humidified atmosphere with $5 \% \mathrm{CO}_{2}$.

\section{RNA Interference}

Cells were seeded in 6-well plate and T25 flask, and allowed to attach before transfection. Cells were transfected with $25 \mathrm{nM}$ siRNA (Ambion, Austin, TX, USA) with FuGENE 6 transfection reagent following the manufacturer's recommendations. After transfection for $24 \mathrm{~h}$, medium was changed and cells were incubated for $24 \mathrm{~h}$ before collected for following experiment.

\section{Cell Growth Inhibition Study Using MTT Assay}

Cells were seeded at 5000 cells/well into 96-well plates. For the experiment in Figure 3A, MCF-7 and MDA-MB-231 cells were treated with serial concentrations of bakuchiol for 24, 48, and $72 \mathrm{~h}$. For the experiment in Figure 3B, MCF-7 and MDA-MB231 cells were treated with serial concentrations of resveratrol for 24, 48, and 72 h. For the experiment in Figure 3C, MCF-7 cells were treated with ethanol alone or $1 \mu \mathrm{g} / \mathrm{ml}$ bakuchiol and/or $1 \mu \mathrm{M}$ ICI 182780 for $72 \mathrm{~h}$. For the experiment in Figure 6A, MCF-7 cells were transfected with siCtrl or sip21, and treated with 0 or $7 \mu \mathrm{g} / \mathrm{ml}$ of bakuchiol for $24 \mathrm{~h}$. After treatment, the cells were washed with PBS and incubated with $0.5 \%$ MTT for $3 \mathrm{~h}$. DMSO was used to dissolve the formazan crystals, and the optical density of $570 \mathrm{~nm}$ of each well was obtained by a multiwell scanning spectrophotometer (Model 550, Bio-Rad, Hercules, CA, USA).

\section{Cell Cycle Analysis Using PI Staining}

For the experiment in Figure 4A, MCF-7 cells and MDA-MB231 cells were treated with varying concentrations of bakuchiol for $24 \mathrm{~h}$. For the experiment in Figure 5A, MCF-7 cells and MDA-MB-231 cells were treated with ethanol alone or $7 \mu \mathrm{g} / \mathrm{ml}$ of bakuchiol and/or $5 \mathrm{mM}$ of caffeine for $24 \mathrm{~h}$. For the experiment in Figure 6B, MCF-7 cells were transfected with siCtrl or sip21, and treated with 0 or $7 \mu \mathrm{g} / \mathrm{ml}$ of bakuchiol for $24 \mathrm{~h}$. After treatment, cells were trypsinized, washed with ice-cold PBS, and fixed with $70 \%$ ethanol at $4^{\circ} \mathrm{C}$ overnight. For staining, the fixed cells were centrifuged to remove ethanol and washed with PBS. Then the cell pellets were resuspended with $50 \mu \mathrm{g} / \mathrm{ml}$ PI and $100 \mu \mathrm{g} / \mathrm{ml}$ RNase A. After $30 \mathrm{~min}$ of incubation at $37^{\circ} \mathrm{C}$, the stained cell suspension was analyzed by using a flow cytometer (Becton Dickinson, San Diego, CA, USA) with an excitation wavelength of $488 \mathrm{~nm}$. The cell cycle distribution was calculated by using MODFIT 3.0 software (Verity Software House, Topsham, ME, USA).

\section{Examination of Bakuchiol-Induced Apoptosis with Annexin V/PI Staining}

For the experiment in Figure 7B, MCF-7 cells were treated with $0-10 \mu \mathrm{g} / \mathrm{ml}$ of bakuchiol for $24 \mathrm{~h}$. The analysis of apoptosis was conducted using annexin V-FITC/PI apoptosis kit in accordance with the manufacturer's protocol.

\section{Measurement of Mitochondrial Membrane Potential with JC-1 Staining}

For the experiment in Figure 7C, MCF-7 cells were treated with $0-10 \mu \mathrm{g} / \mathrm{ml}$ of bakuchiol for $24 \mathrm{~h}$. Changes in mitochondrial membrane potential were measured by using a flow cytometer with JC-1 dye in accordance with the instructions of the manufacturer.

\section{RNA Extraction, Reverse Transcription, and Quantitative Real-Time PCR}

For the experiment in Figure 2E, medaka fish $(n=10)$ were exposed to $0.5 \mu \mathrm{g} / \mathrm{ml}$ bakuchiol for $24 \mathrm{~h}$. For the experiment in Figure 3C, MCF-7 cells were treated with ethanol alone or $1 \mu \mathrm{g} / \mathrm{ml}$ bakuchiol and/or $1 \mu \mathrm{M}$ ICI 182780 for $72 \mathrm{~h}$. For the experiment in Figure 3D, MCF-7 cells were treated with 0, 4, or $7 \mu \mathrm{g} / \mathrm{ml}$ of bakuchiol for $24 \mathrm{~h}$. For the experiment in Figure 4C, 

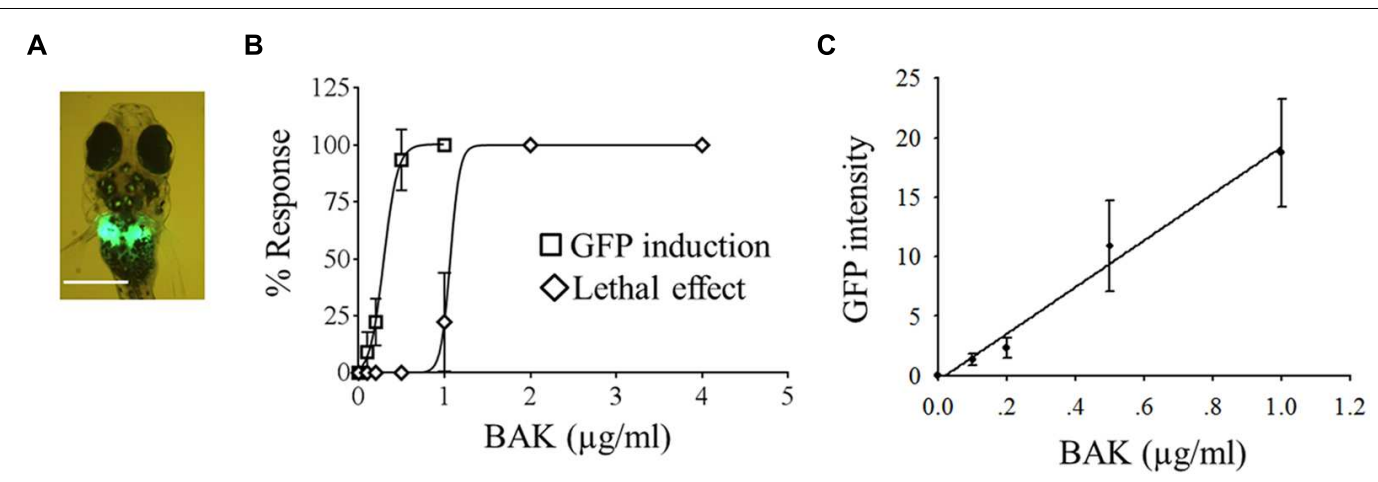

D

E

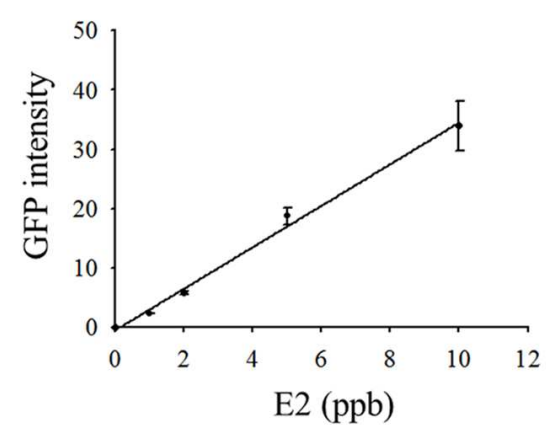

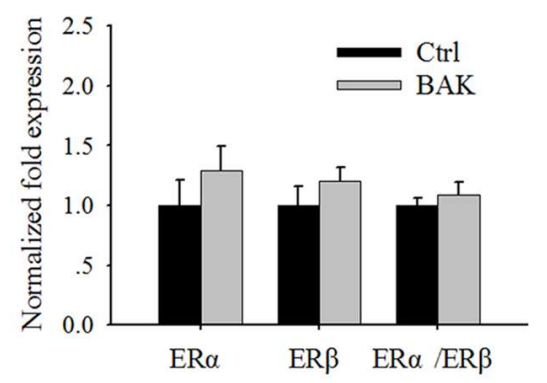

FIGURE 2 | Screening of in vivo estrogenic activity with transgenic medaka. (A) Bakuchiol induced GFP expression in liver, the white bar indicates $100 \mu \mathrm{m}$. (B) $L C_{50}$ and $E C_{50}$ of fish after exposure to bakuchiol for $24 \mathrm{~h}$. Correlation between different concentrations of (C) bakuchiol and (D) E2, and the induced GFP signal intensity. (E) Analysis of mRNA expression of ER $\alpha$ and ER $\beta$ by using real-time PCR. Fish $(n=10)$ were exposed to $0.5 \mu \mathrm{g} / \mathrm{ml}$ bakuchiol for $24 \mathrm{~h}$. $18 \mathrm{~S} r R N A$ was used as the internal reference. BAK, bakuchiol.

MCF-7 cells and MDA-MB-231 cells were treated with ethanol or $7 \mu \mathrm{g} / \mathrm{ml}$ of bakuchiol for $24 \mathrm{~h}$. After the treatment, total RNA of the fish larvae and breast cancer cells was extracted by using the TRIzol reagent in accordance with the manufacturer's instructions. Total RNA sample was treated with RQ1 RNasefree DNase to decontaminate the genomic DNA, and cDNA was obtained from total RNA by using high capacity RNAto-cDNA master mix. Real-time PCR was performed with the StepOnePlus ${ }^{\text {TM }}$ Real-Time PCR System (Applied Biosystems, Carlsbad, CA, USA), by using the Kapa SYBR FAST qPCR kit, and following the recommendations of the manufacturer. Primers were listed in Table $\mathbf{1}$.

\section{Cell Protein Extraction and Western Blot Analysis}

For the experiment in Figure 4B, MCF-7 cells and MDA-MB231 cells were treated with varying concentrations of bakuchiol for $24 \mathrm{~h}$. For the experiment in Figure 5B, MCF-7 cells and MDA-MB-231 cells were treated with ethanol alone or $7 \mu \mathrm{g} / \mathrm{ml}$ of bakuchiol and/or $5 \mathrm{mM}$ of caffeine for $24 \mathrm{~h}$. For the experiment in Figure 6D, MCF-7 cells were transfected with siCtrl or sip21, and treated with 0 or $7 \mu \mathrm{g} / \mathrm{ml}$ of bakuchiol for $24 \mathrm{~h}$. For the experiment in Figures 7D,E, MCF-7 cells were treated with $0-10 \mu \mathrm{g} / \mathrm{ml}$ of bakuchiol for $24 \mathrm{~h}$. After treatment, the cells

TABLE 1 | Primers for quantitative real-time PCR.

\begin{tabular}{|c|c|c|c|}
\hline & Gene & Forward $\left(5^{\prime}-3^{\prime}\right)$ & Reverse $\left(5^{\prime}-3^{\prime}\right)$ \\
\hline \multirow[t]{3}{*}{ Fish } & 18S rRNA & CCTGCGGCTTAATTGACCC & GACAAATCGCTCCACCAACT \\
\hline & $\mathrm{ER} \alpha$ & ATTGGAGGTCCATCCACTG & TGAGTITGAGCACACGGAAG \\
\hline & $\mathrm{ER} \beta$ & AGGAGCATCCAAGGACACAC & GCCGACTTCGTAGCACTाC \\
\hline \multirow[t]{7}{*}{ Cell } & GAPDH & TCCCTGAGCTGAACGGGAAG & GGAGGAGTGGGTG TCGCTGT \\
\hline & $\mathrm{ER} \alpha$ & АGСТССТССТСАТССТСТСС & TCTCCAGCAGCAGGTCATAG \\
\hline & $\mathrm{ER} \beta$ & CСTCAAAAGAGTCCСTGGTG & CTTCACACGACCAGACTCCA \\
\hline & p21 & GAGGCCGGGATGAGTTGGGAGGAG & CAGCCGGCGTITGGAGTGGTAGAA \\
\hline & p53 & ССССTССTGGССССTGTCATCTTC & GCAGCGCCTCACAACCTCCGTCAT \\
\hline & ATM & CCCCTTGTGTATGAGCAGGTG & CGGATTATCCTGAGAAGCTC \\
\hline & ATR & АСАТTCCСTGATCCTACATCATG & TTCAATAGATAACGGCAGTCCTG \\
\hline
\end{tabular}



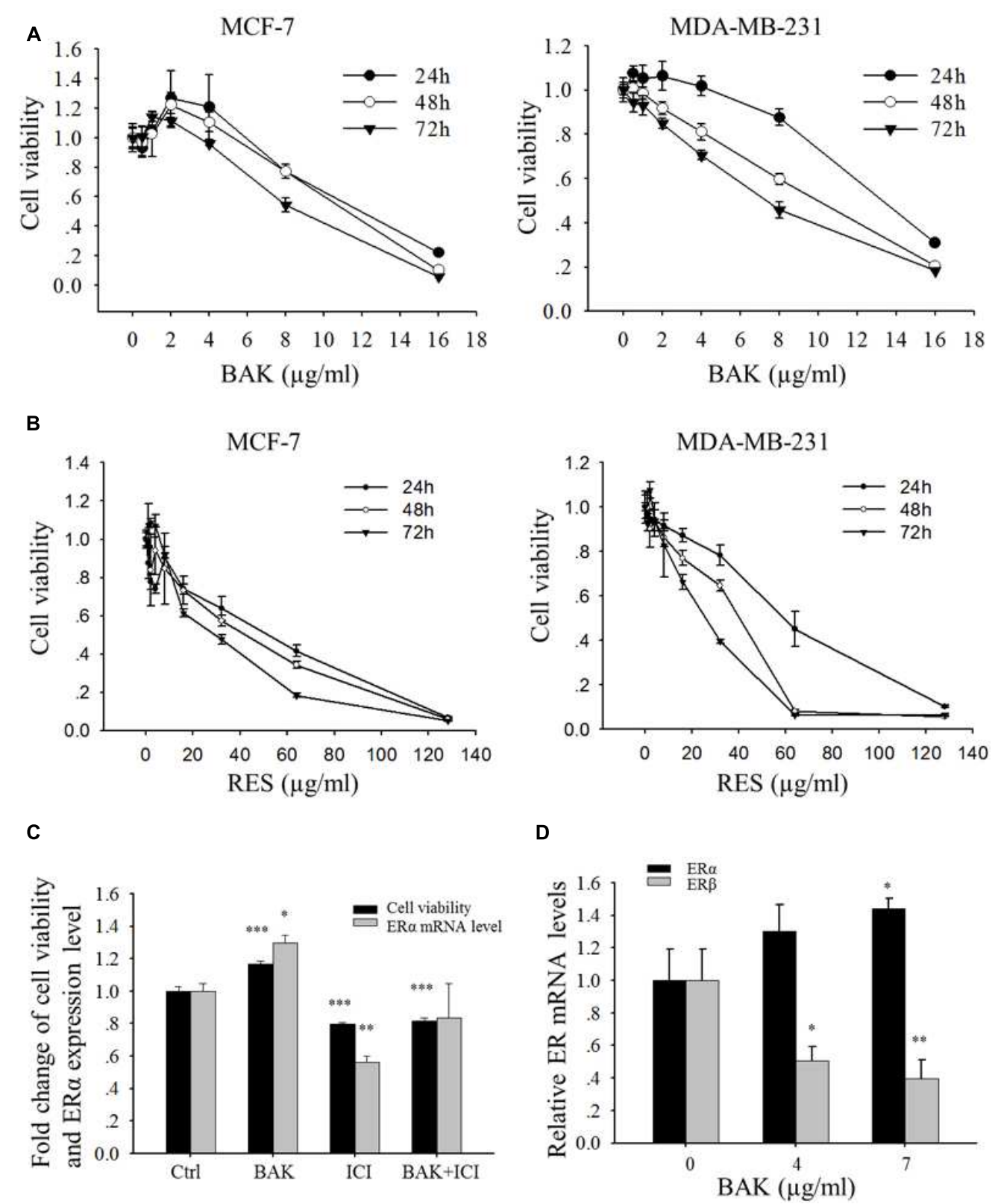

FIGURE 3 | Effects of bakuchiol on cell viability of breast cancer cells. MCF-7 and MDA-MB-231 cells were treated with serial concentrations of (A) bakuchiol and (B) resveratrol for 24, 48 and 72 h, and cell proliferation was monitored by using MTT assay. The data were expressed as fold change of viability compared to the vehicle control (ethanol) with standard deviation. (C) Fold changes of cell viability and ER $\alpha$ mRNA levels of MCF-7 cells, which were treated with ethanol alone or $1 \mu \mathrm{g} / \mathrm{ml}$ bakuchiol and/or $1 \mu \mathrm{M} \mathrm{ICl} 182780$ for $72 \mathrm{~h}$ (compared with control group, ${ }^{*} p<0.05,{ }^{* *} p<0.01,{ }^{* * *} p<0.001$, one-way ANOVA). (D) ER $\alpha$ and ER $\beta$ mRNA levels of MCF-7 cells, which were treated with 0 , 4, or $7 \mu \mathrm{g} / \mathrm{ml}$ of bakuchiol for $24 \mathrm{~h}$ (compared with control group, ${ }^{*} p<0.05$, ${ }^{* *} p<0.01$, $* * * p<0.001$, one-way ANOVA). BAK, bakuchol; RES, resveratrol; ICI, ICl 182780; Ctrl, control.

were collected and washed twice with ice-cold PBS. Cell pellets were lysed with ice-cold RIPA buffer, which contained $1 \mathrm{mM}$ PMSF and $1 \%$ protease inhibitor cocktail. The supernatant was collected and same amounts of proteins were mixed with loading buffer, and heated at $95^{\circ} \mathrm{C}$ for $10 \mathrm{~min}$ before loading onto $10 \%$ SDS-polyacrylamide gel. The separated proteins were then transferred to a PVDF membrane (GE Healthcare, Milwaukee, WI, USA), and the membrane was blocked with 5\% non-fat milk for $1 \mathrm{~h}$ at room temperature. Then, the membrane was probed with an appropriate primary antibody overnight at $4^{\circ} \mathrm{C}$. After washing three times with PBT, the membrane was incubated with HRP-conjugated secondary antibody for $1 \mathrm{~h}$ at room temperature before visualization with the ECL Prime Western blotting detection system. Antibodies were listed in Table 2. Image analysis was performed by using a Fujifilm luminescent image analyzer (Fujifilm Life Science, Stamford, CT, USA). 
A

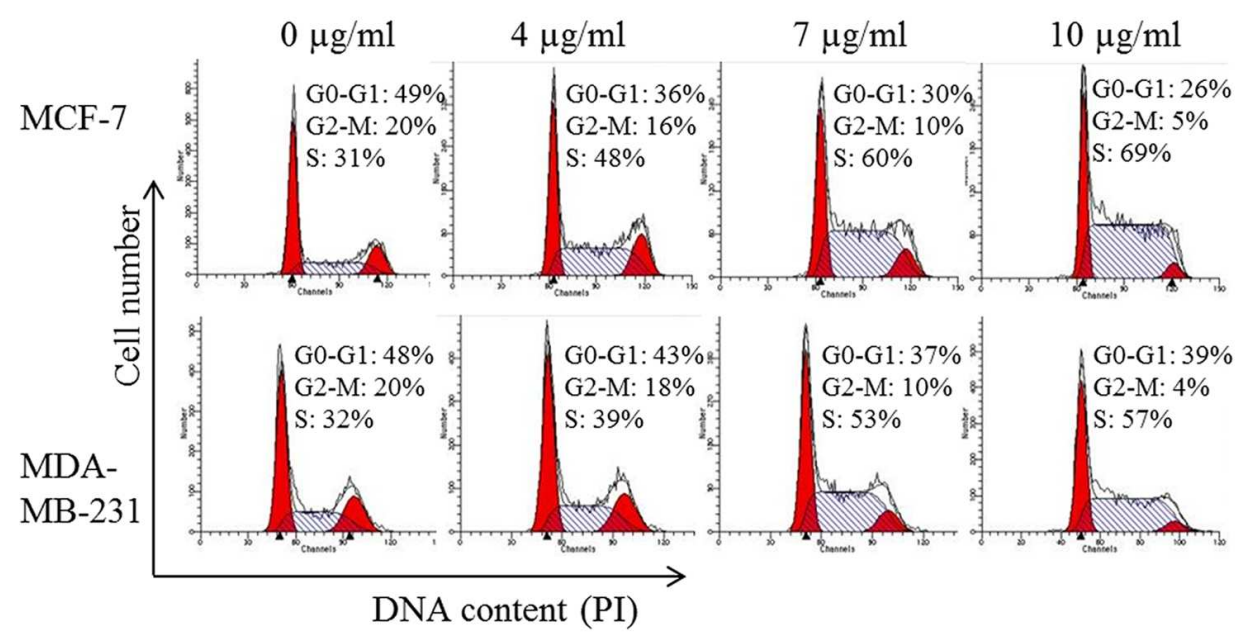

B

$\mathrm{MCF}-7$

MDA-MB-231

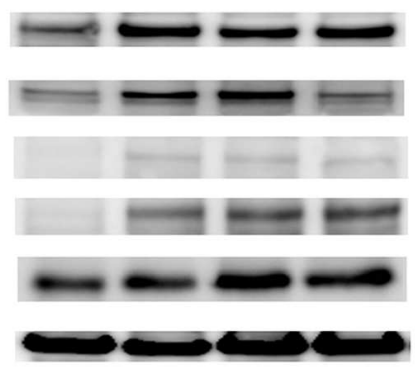

$\longrightarrow-\longrightarrow$ P-Cdc2 (Tyr15)

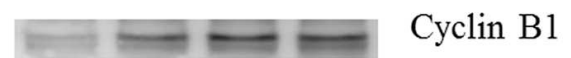

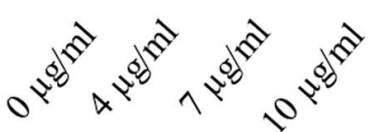

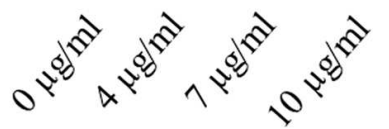

C

$\mathrm{MCF}-7$

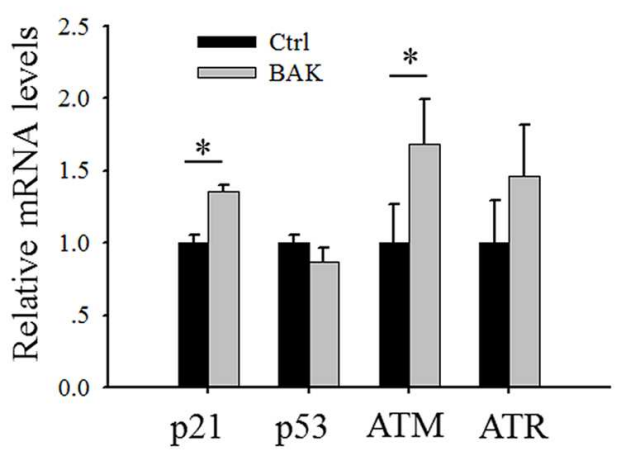

MDA-MB-231

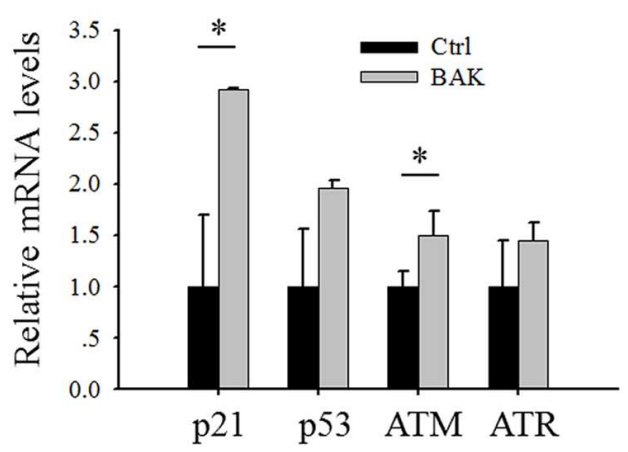

FIGURE 4 | Bakuchiol induced alteration in cell cycle and cell cycle regulator expression in breast cancer cells. (A,B) Cells were treated with varying concentrations of bakuchiol as labeled in the figure for $24 \mathrm{~h}$. (A) Cell cycle analysis with PI staining. (B) Expression levels of P-Cdc2 (Tyr15), Cyclin B1, P-Wee1 (Ser 642), Myt1, p21 (Waf1/Cip1) and $\beta$-Actin analyzed with Western blot (C) p21, p53, ATM and ATR mRNA expressions in cells treated with ethanol or $7 \mu \mathrm{g} / \mathrm{ml}$ of bakuchiol for $24 \mathrm{~h}$. The data represent the mean \pm SD of the values from three separate RNA samples (* $p<0.05$, student's $t$-test). Ctrl, control; BAK, bakuchol.

\section{Cell Morphology Observation}

For the experiment in Figure 7A, MCF-7 cells were seeded on sterilized cover slide, and treated with $0-10 \mu \mathrm{g} / \mathrm{ml}$ of bakuchiol for $24 \mathrm{~h}$. After treatment, an inverted microscope (model DMI 3000B, Leica Microsystems, Germany) was used to observe and record the cell morphology. 


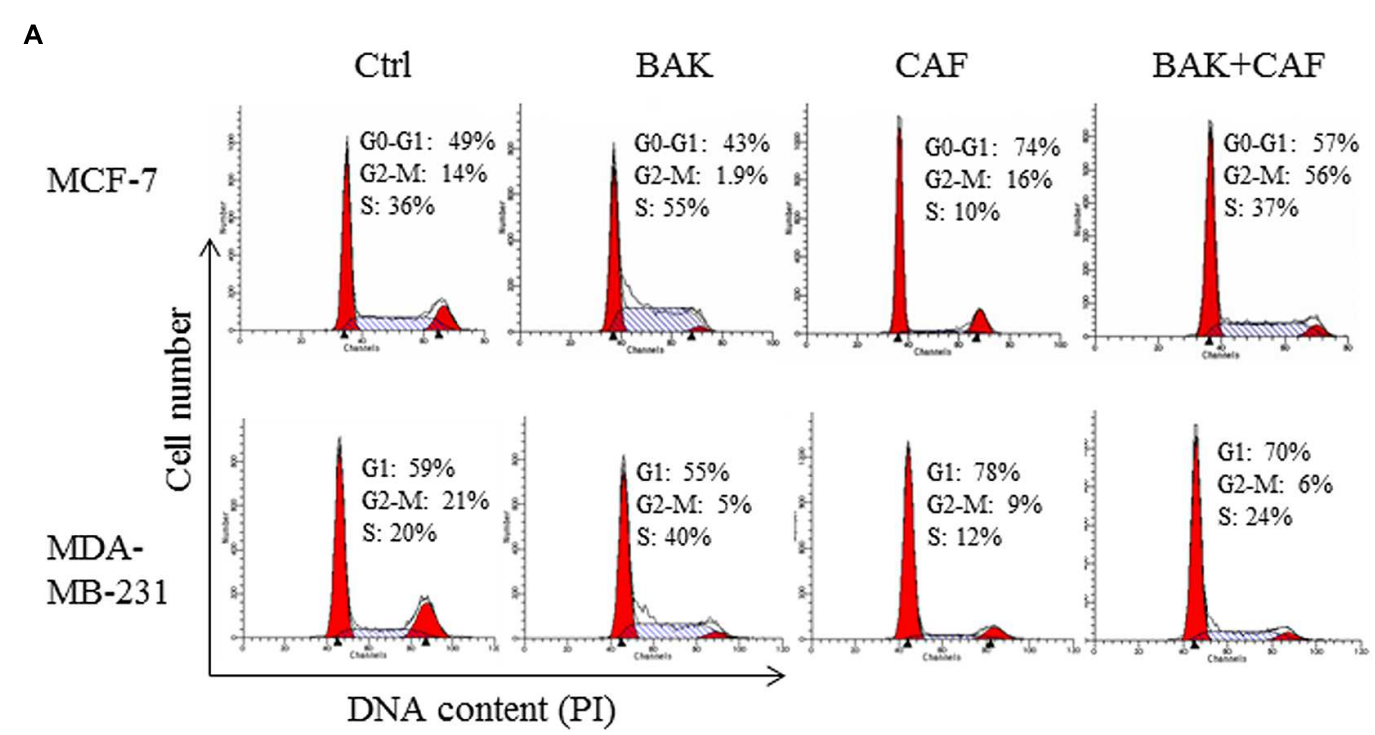

B
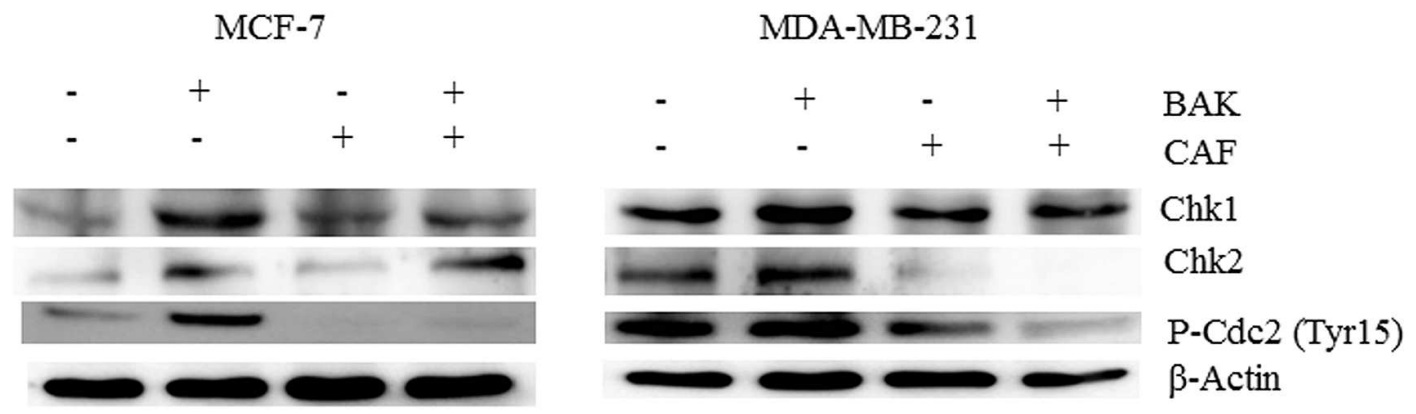

FIGURE 5 | Caffeine rescued bakuchiol-induced S phase arrest in breast cancer cells. Cells were treated with ethanol alone or $7 \mu \mathrm{g} / \mathrm{ml}$ of bakuchiol and/or $5 \mathrm{mM}$ of caffeine for $24 \mathrm{~h}$. (A) representative cell cycle histograms from three individual experiments of control and treatment with percentage of cell cycle phase indicated. (B) Western blot analysis of Chk1, Chk2, P-Cdc2 (Tyr15) in total cell lysates. $\beta$-Actin was used as loading control. Ctrl, control; BAK, bakuchiol, CAF, caffeine.

\section{Zebrafish Xenografts Establishment and Fish Exposure}

Wild-type $\mathrm{AB}$ zebrafish embryos were maintained in embryo medium containing PTU at a $0.003 \% \mathrm{w} / \mathrm{v}$ concentration to remove the surface pigmentation. For the zebrafish xenotransplantation, $48 \mathrm{hpf}$ embryos were dechorionated and anesthetized in and $0.004 \mathrm{w} / \mathrm{v}$ tricaine before cell injection. Before cell injection, cells were labeled with the Green CMFDA according to manufacturer's protocol. After staining and washing, cells were loaded into a pulled glass micropipette and attached to an air driven microinjector (Eppendorf FentoJet Express). Approximately 300 cells were injected into the yolk sac of embryos. After injection, embryos were exposed with ethanol (solvent control) or $0.5 \mu \mathrm{g} / \mathrm{ml}$ of bakuchiol. The exposed embryos were maintained for $1 \mathrm{~h}$ at $28^{\circ} \mathrm{C}$ and then placed in to incubator at $34^{\circ} \mathrm{C}$ for $71 \mathrm{~h}$. Injection was performed using an Olympus SZX12 dissecting microscope, and the xenotransplanted embryos were examined by using a Olympus BX61 flurescence microscope. The integrated fluorescence intensity was quantified by image analysis software ImageJ.
All procedures with fish were conducted following the License to Conduct Experiments approved by the Government of the Hong Kong SAR Department of Health [Ref. (15-10) in DH/HA\&P/8/2/5 Pt.3].

\section{Statistical Analysis}

Statistical analyses were conducted by using the SPSS 13.0 program. Experiments were carried out three times and the data are presented as mean values \pm standard deviation. Student's $t$-test, one sample $t$-test and one-way ANOVA were used to analyze the data. A $p$-value of $<0.05$ is considered to be statistically significant.

\section{RESULTS}

\section{Bakuchiol Exhibits In Vivo Estrogenic Activity}

Bakuchiol induced GFP expression in the liver of the fish (Figure 2A), and $\mathrm{LC}_{50}$ and $\mathrm{EC}_{50}$ (indicated by GFP induction) of 
A

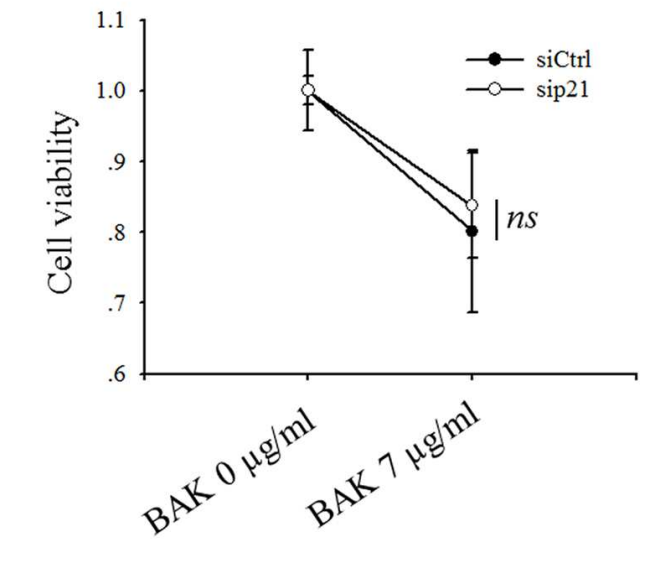

C

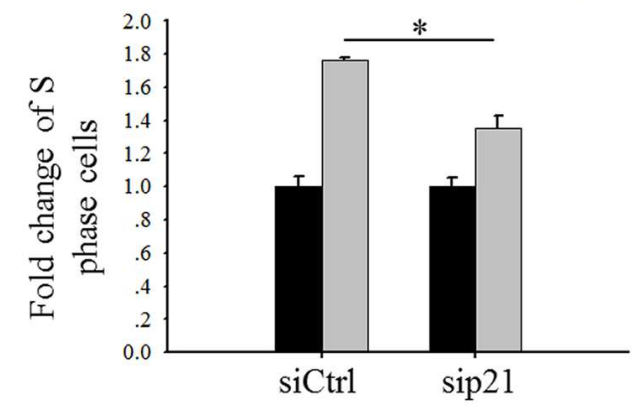

B

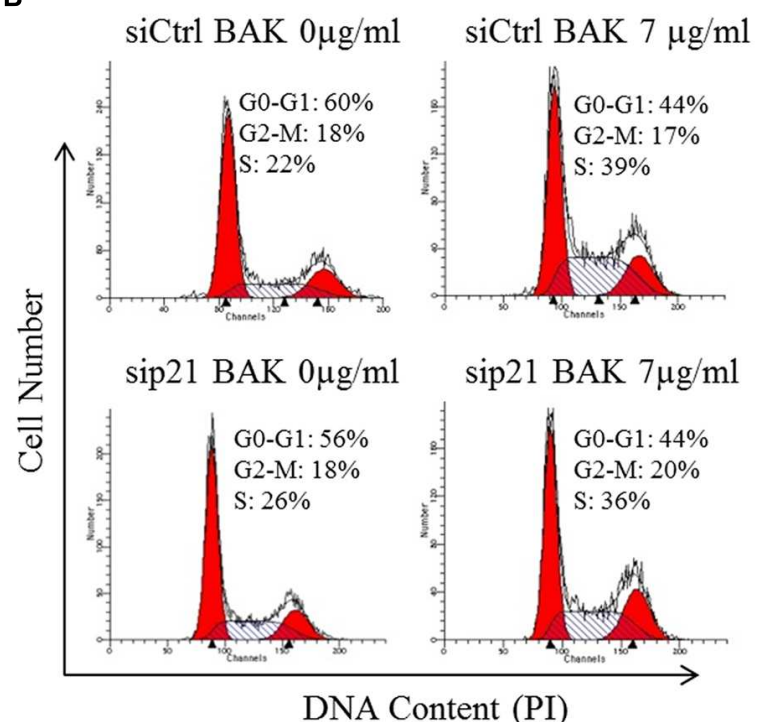

D

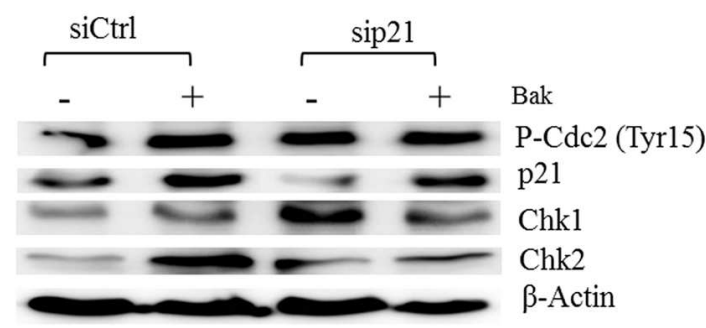

FIGURE 6 | Knock-down of p21 marginally rescued the bakuchiol-induced S phase arrest. MCF-7 cells were transfected with siCtrl or sip21, and treated with 0 or $7 \mu \mathrm{g} / \mathrm{ml}$ of bakuchiol for $24 \mathrm{~h}$. (A) Cell viability was monitored by MTT assay. The data are expressed as fold change of cell viability with standard deviation (ns $p>0.05$, student's $t$-test). (B) Cell cycle distribution was studied with PI staining. (C) Fold change of cell number in $S$ phase $\left({ }^{*} p<0.05\right.$, student's $t$-test).

(D) Western blot analysis of p21, Chk1, Chk2, P-Cdc2 (Tyr15) in total cell lysates. $\beta$-Actin was used as loading control. Ctrl, control; BAK, bakuchiol.

bakuchiol were 1.1 and $0.3 \mu \mathrm{g} / \mathrm{ml}$ respectively (Figure $2 \mathrm{~B}$ ). The signal intensity of the induced GFP increased in a concentrationdependent manner (Figure 2C). Phytoestrogen usually has weak estrogenic activity. To make the screening results comparable with strong estrogenic compound, the dose-dependent response of transgenic larvae was analyzed with E2 (Figure 2D). The GFP signal intensity induced by bakuchiol was compared with the result of the E2 exposure. The GFP intensity of the $\mathrm{EC}_{50}$ $(0.3 \mu \mathrm{g} / \mathrm{ml})$ of bakuchiol was comparable to the estrogenicity of $1.6 \mathrm{ppb}(\sim 1.6 \mu \mathrm{g} / \mathrm{l})$ E2. The results suggested that bakuchiol is a weak estrogen; about 180 times weaker than E2. The expression levels of the ER $\alpha$ and ER $\beta$ of fish after $0.5 \mu \mathrm{g} / \mathrm{ml}$ bakuchiol treatment were studied with quantitative real-time PCR. Compared with the control group, both $\operatorname{ER} \alpha$ and $\operatorname{ER} \beta$ exhibit no significant difference in the bakuchiol treatment group the trend of upregulation, although there is (Figure 2E), even GFP expression was induced in $94 \%$ of the fish after $0.5 \mu \mathrm{g} / \mathrm{ml}$ bakuchiol exposure (Figure 2B). Moreover, bakuchiol did not show a significant preference to either $\operatorname{ER} \alpha$ or $\operatorname{ER} \beta$ in whole fish (Figure 2E).

\section{Bakuchiol Induces Cell Growth Inhibition}

The cell growth of two breast carcinoma cell lines, MCF-7 and MDA-MB-231, in the presence of various concentrations of bakuchiol, was examined. In the $\mathrm{ER} \alpha$-positive breast carcinoma cell line MCF-7, bakuchiol exerted a biphasic effect on the growth of the cells under the experimental conditions (at 24, 48, and $72 \mathrm{~h}$ ) - stimulating cellular proliferation at concentrations below $2 \mu \mathrm{g} / \mathrm{ml}$, but inhibiting cell proliferation in a dosedependent manner above $2 \mu \mathrm{g} / \mathrm{ml}$ (Figure 3A). $\mathrm{IC}_{50}$ in MCF7 cells were $12.1-9.3 \mu \mathrm{g} / \mathrm{ml}$ for $24-72 \mathrm{~h}$ exposure. In the $\mathrm{ER} \alpha$-negative breast cancer cell line MDA-MB-231, bakuchiol exhibited a marked growth inhibitory effect in dose- and time-dependent manners ( $\mathrm{IC}_{50}: 13.1-8.9 \mu \mathrm{g} / \mathrm{ml}$ ). The $\mathrm{IC}_{50}$ of resveratrol in breast cancer cells were $2.72-4.15$ times of that in bakuchiol (Figure 3B), indicating that bakuchiol exhibits stronger anti-breast cancer effect. When MCF-7 cells were co-treated with low dose of bakuchiol $(1 \mu \mathrm{g} / \mathrm{ml})$ and $1 \mu \mathrm{M} E R \alpha$ antagonist ICI 182780, the proliferative effects of bakuchiol on ER $\alpha$-positive cells was blocked (Figure 3C). The bakuchiol-induced ER $\alpha$ expression was also eliminated 
A

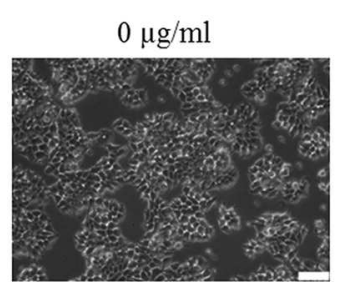

$7 \mu \mathrm{g} / \mathrm{ml}$

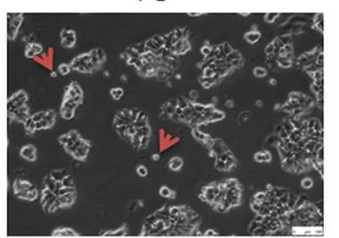

B

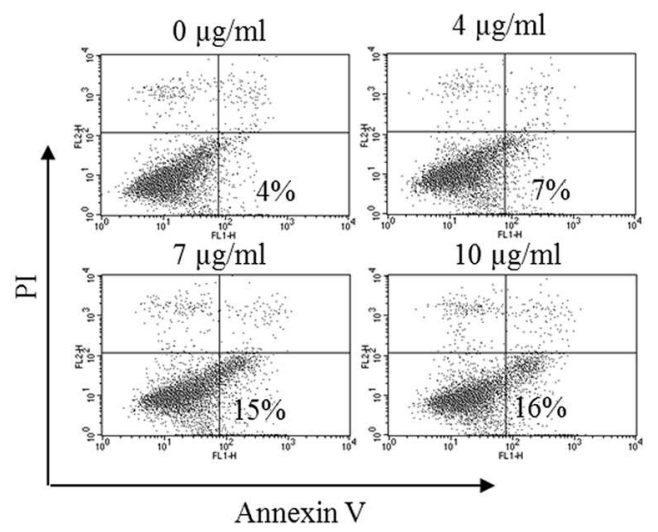

$10 \mu \mathrm{g} / \mathrm{ml}$
C
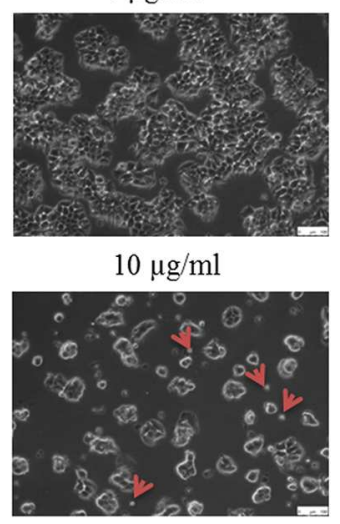

D

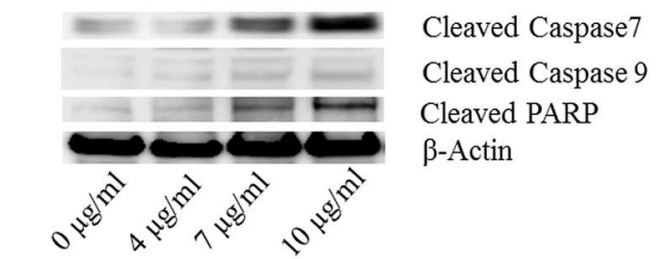

E
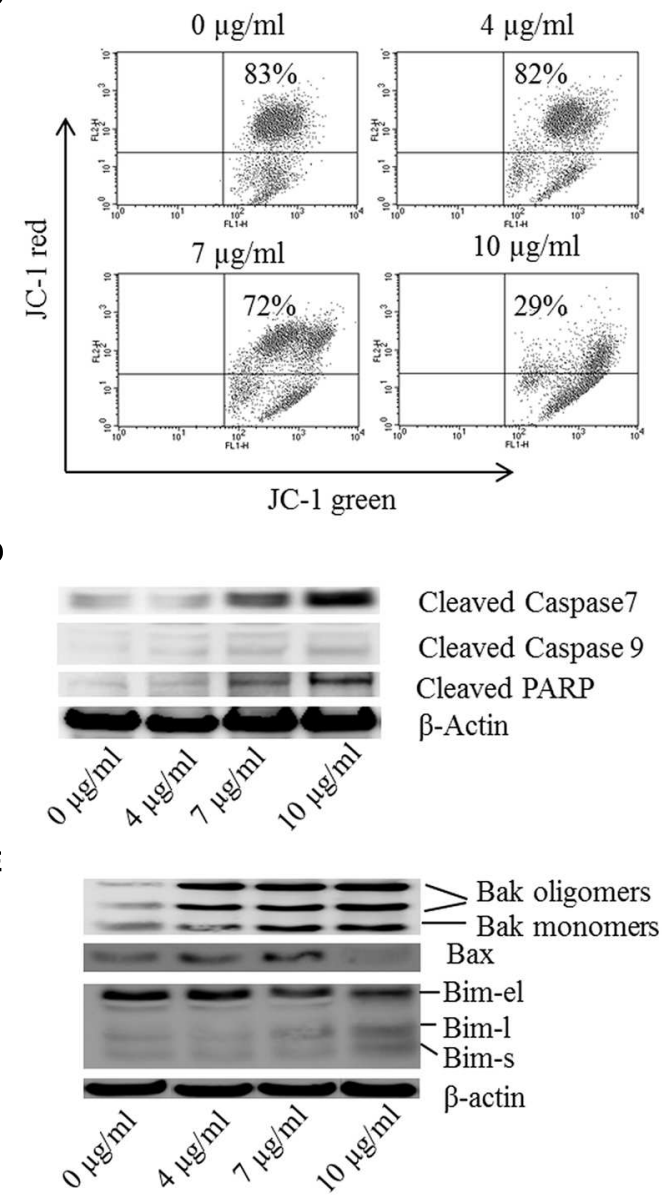

FIGURE 7 | Bakuchiol induced apoptosis in MCF-7 cells. MCF-7 cells were treated with 0-10 $\mu \mathrm{g} / \mathrm{ml}$ of bakuchiol for $24 \mathrm{~h}$. (A) Morphology observation of bakuchiol treated MCF-7 under bright field. Small apoptotic bodies are labeled with red arrows. The white bar indicates $100 \mu \mathrm{m}$. (B) Representative flow cytometry results of annexin V/PI analysis. (C) JC-1 staining for analysis of mitochondrial membrane potential. Western blot analysis of expression levels of (D) Caspase family protein, including Cleaved Caspase 7, Cleaved Caspase 9, and Cleaved PARP, and (E) Bcl-2 family protein, including Bak, Bax, and Bim. $\beta$-Actin was used as loading control.

by ICI 182780 (Figure 3C). Upon treated with high doses (4 and $7 \mu \mathrm{g} / \mathrm{ml}$ ) of bakuchiol, the expression levels of ER $\alpha$ were induced and ER $\beta$ were suppressed in MCF-7 cells (Figure 3D).

\section{Bakuchiol Induces S Phase Arrest and Expression Level Change of Cell Cycle Regulator}

After the cells were treated for $24 \mathrm{~h}$ with increasing concentrations $(0-10 \mu \mathrm{g} / \mathrm{ml})$ of bakuchiol, a significant dose-dependent accumulation of cells in S phase in both MCF-7 and MDA-MB-231 (Figure 4A) resulted. We then next examined the protein levels of cell cycle regulators (Figure 4B). After the cells were treated with $0-10 \mu \mathrm{g} / \mathrm{ml}$ of bakuchiol, the expression level of P-Cdc2 (Tyr15) was up-regulated, accompanied with up-regulation of Myt1 and P-Wee1 (Ser642). In addition, bakuchiol also induced the upregulation of p21 and Cyclin B1. The up-regulation of $\mathrm{p} 21$ was also confirmed with real-time
PCR (Figure 4C). The ATM mRNA expression levels were also significantly induced in both MCF-7 and MDA-MB-231 cells ( $p<0.05$, both, Figure 4C). However, there is only an upregulated trend of ATR mRNA level, with no significance. No significant change of p53 mRNA level was observed in both MCF-7 and MDA-MB-231 cells (Figure 4C).

\section{Caffeine Rescues Bakuchiol-Induced S Phase Arrest}

When the cells were pre-treated with caffeine, a known ATM/ATR inhibitor, that can inhibits ATM/ATR in MCF-7 and MDA-MB-231 cells, at the concentration of $5 \mathrm{mM}$ (Yu et al., 2013), the bakuchiol-induced accumulation of $S$ phase cells was rescued by caffeine pre-treatment in both MCF-7 and MDAMB-231 cells (Figure 5A). The up-regulated expression levels of P-Cdc2 (Tyr15), Chk1 and Chk2 induced by the bakuchiol treatment were also rescued by pre-treatment with caffeine (Figure 5B). 
TABLE 2 | List of antibodies.

\begin{tabular}{llc}
\hline Antibody & \multicolumn{1}{c}{ Company } & Catalog number \\
\hline P-Cdc2 (Tyr15) & Cell Signaling Technology & 9111 \\
Cyclin B1 & Cell Signaling Technology & 4138 \\
P-Wee1 (Ser642) & Cell Signaling Technology & 4910 \\
Myt1 & Cell Signaling Technology & 4282 \\
P21 Waf1/Cip1) & Cell Signaling Technology & 2947 \\
Chk1 & Cell Signaling Technology & 2360 \\
Chk2 & Cell Signaling Technology & 6334 \\
Cleaved Caspase7 & Cell Signaling Technology & 9491 \\
Cleaved Caspase9 & Cell Signaling Technology & 9501 \\
Cleaved PARP & Cell Signaling Technology & 5625 \\
Bak & Cell Signaling Technology & 6947 \\
Bax & Cell Signaling Technology & 5023 \\
Bim & Cell Signaling Technology & 2933 \\
$\beta$-Actin & Cell Signaling Technology & 3700 \\
Anti-rabbit lgG & Cell Signaling Technology & 7074 \\
Anti-mouse IgG & Cell Signaling Technology & 7076 \\
\hline
\end{tabular}

\section{Depletion of p21 Marginally Rescues S-Phase Arrest Caused by Bakuchiol}

When MCF-7 cells were transfected with sip21, the expression level of p21 was down-regulated (Figure 6D). Depletion of p21 marginally rescued bakuchiol-induced inhibitory effect, however, the difference of cell viability between bauchiol-treated siCtrl cells and sip21 cells are not significant $(p>0.05$, Figure 6A). In both siCtrl and sip21 transfection cells, bakuchiol induced $\mathrm{S}$ phase arrest (Figure 6B). The level of S phase cell accumulation was more significant in siCtrl cells than in sip21 cells $(p<0.05$, Figure 6C). Depletion of $\mathrm{p} 21$ led to the increased expression of Chk1 and Chk2 (Figure 6D). The bakuchiol-induced Chk2 expression was more significant in siCtrl cells than in sip21 cells $(p<0.001$, Figure 6D).

\section{Bakuchiol Induces Apoptosis of MCF-7 Cells}

Morphological change was observed under inverted microscope with bright field (Figure 7A). With the bakuchiol concentration increasing, more of the cells became rounded, shrank and were unattached. Besides, more small apoptotic bodies broken from cells can be observed (see red arrow). By using a flow cytometric analysis after annexin V/PI staining, the effects of bakuchiol on breast cancer cell apoptosis were determined. Exposure of MCF-7 cells to bakuchiol elicits a increase in early apoptotic cells, in a dose-dependent manner (Figure 7B). Besides, flow cytometric analysis of mitochondrial transmembrane potential $\Delta \psi \mathrm{m}$ by using JC-1 staining revealed that bakuchiol reduced $\Delta \psi \mathrm{m}$ of MCF-7 cells dose-dependently (Figure $7 \mathrm{C}$ ). While in MDA-MB-231 cells, bakuchiol did not affect the cell morphology and apoptotic rate under the exposure conditions (data not shown).

The expression levels of Caspase family members and their substrates were determined with Western blot (Figure 7D). After $24 \mathrm{~h}$ of treatment, the expression levels of cleaved Caspase 7,
Caspase 9 and PARP were upregulated by bakuchiol. It has been demonstrated that $\mathrm{Bcl}-2$ family proteins control mitochondrial membrane permeabilization, which is essential for apoptotic regulations. We detected the expression levels of pro-apoptotic Bcl-2 family proteins (Figure 7E). The levels of Bim-1, Bim-s, Bak monomers, Bak oligomers and Bax were induced by bakuchiol.

\section{Bakuchiol Exhibits In Vivo Anti-breast Cancer Effect}

After MCF-7 cells were injected into the yolk sac of $48 \mathrm{hpf}$ zebrafish embryos, cell mass formation was observed after 72 h (Figure 8A). Compared with control group, bakuchiol significantly inhibited the cell mass formation, which was indicated by the integrated fluorescent signal of CMFDA-labeled cells ( $p<0.05$, Figure 8B). Importantly, there was no significant difference in the mortality between control group and treatment group ( $p>0.05$, data not shown).

\section{DISCUSSION}

\section{Bakuchiol May Act as a SERM and an Anti-breast Cancer Drug}

In current study, bakuchiol exhibits estrogenic activity in both in vivo and in vitro models. Bakuchiol-induced Chg expression in the liver of the transgenic medaka fish suggests that bakuchiol is an $\mathrm{ER} \alpha$ agonist in the liver (Chen et al., 2008). When medaka fish were exposed to $0.5 \mu \mathrm{g} / \mathrm{ml}$ of bakuchiol, GFP expression was induced in $94 \%$ of the fish. However, the increased expressions of both $\operatorname{ER} \alpha$ and $\operatorname{ER} \beta$ in the whole fish were not significant, and bakuchiol did not show preference to either ER $\alpha$ or ER $\beta$, which all suggest that bakuchiol may act as an ER agonist in some organs and antagonist in other organs in the fish. In previous studies, bakuchiol exhibited different binding abilities to $E R \alpha$ and $E R \beta$ in different in vitro models, which also implies that bakuchiol has the role of a SERM (Xin et al., 2010; Lim et al., 2011). Another two active ingredients of Fructus Psoraleae, named psoralen and isopsoralen, have also been reported with in vitro estrogenic activities (Xin et al., 2010; Lim et al., 2011). However, GFP could not be induced by these two compounds in transgenic fish in current study (data not shown). The in vivo estrogenic activity of bakuchiol suggests an advantage over other phytoestrogens.

In the ER $\alpha$-positive breast carcinoma cell line MCF-7, bakuchiol exerts a biphasic effect on the growth of the cells, which is the stimulating of cellular proliferation at low concentrations and inhibiting of growth in a dose-dependent manner at elevated doses. It has been revealed that activation of ER $\alpha$ could promote breast cancer cell proliferation and breast tumor growth (Paruthiyil et al., 2004). Our in vitro study confirmed the estrogenic activity of low dose of bakuchiol. Moreover, the biphasic effect of bakuchiol on the growth and ER $\alpha$ expression of MCF-7 cells suggests that bakuchiol is an ER $\alpha$ agonist at low concentrations and antagonist at high concentrations in breast tissue. $\mathrm{S}$ phase arrest is observed in both bakuchiol-treated breast 
A

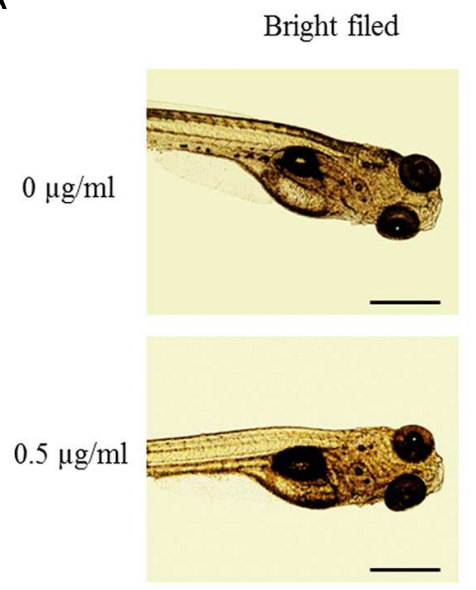

Florescent

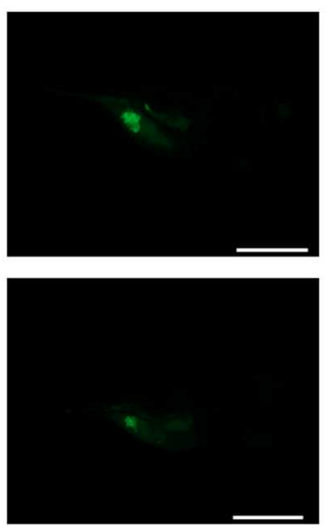

B

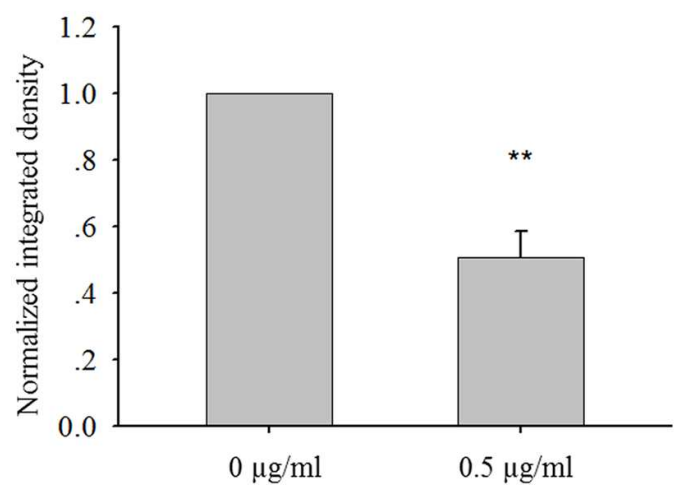

FIGURE 8 | Bakuchiol inhibited in vivo cell mass formation in zebrafish. (A) 300 MCF-7 cells were injected into the yolk sac of 48 hpf zebrafish embryos. 60 embryos were treated with ethanol (solvent control) or $0.5 \mu \mathrm{g} / \mathrm{ml}$ of bakuchiol for $72 \mathrm{~h}$. Triplicates for each condition were performed. Representative bright field and fluorescent images of embryos in both control and treatment groups showing cell mass in the yolk sac area were shown. The black and white bars indicate $500 \mu \mathrm{m}$. (B) Statistical analysis of integrated fluroscent intensity of cell mass in control and treatment group $\left(^{*} p<0.05\right.$, one sample $t$-test). Ctrl, control; BAK, bakuchiol.

cancer cell lines. However, the level of $S$ phase accumulation in $\mathrm{ER} \alpha$-positive MCF-7 cells was higher than that in ER $\alpha$-negative MDA-MB-231 cells. Besides, bakuchiol only induce apoptosis in MCF-7 cells, not in MDA-MB-231 cells, which all suggests that $\mathrm{ER} \alpha$ antagonist effect of bakuchiol contributes to the inhibition of breast cancer cell growth. The bakuchiol-induced ER $\beta$ level may also contribute to the inhibitory effects, since binding to $\operatorname{ER} \beta$ may induce heterodimerization with $\mathrm{ER} \alpha$ and hence silence its activation of genes stimulating cell proliferation (Rice and Whitehead, 2006). The anti-breast cancer effect of bakuchiol was further proved in the zebrafish MCF-7 cell xenotransplantation assay. When xenotrasplanted zebrafish embryos were exposed to $0.5 \mu \mathrm{g} / \mathrm{ml}$ bakuchiol, the cell mass was significantly reduced without inducing higher mortality.

The breast cancer cell promoting effect is only achieved at the low concentration of bakuchiol, and the higher concentrations exhibit opposite effect, which is an advantage over estrogen used in HRT. However, high dose of phytoestrogens may have adverse side effects, such as the endocrine disruption of brain and reproductive track (Patisaul and Jefferson, 2010). It is still not clear if higher doses of bakuchiol will exhibit positive effect that overcomes its negative side effect. Thus, bakuchiol may have the potential to be used in HRT and breast cancer treatment, based on its in vitro and in vivo estrogenic effect and antibreast cancer effect, but further study is necessary to prove its safety.

\section{Bakuchiol Induces S Phase Arrest in Breast Cancer Cells Through Inactivation of Cdc2}

Cell cycle entry into mitotic phase is initiated by the dephosphorylation of two inhibitory residues, Tyr15 and Thr14 of Cdc2, followed by activation of the Cdc2-Cyclin B1 complex
(Zhou and Elledge, 2000). The Weel kinase family consists of Wee1 and Myt1, which can phosphorylate Cdc2 to prevent cell entry into mitosis. After treatment with bakuchiol, the expression levels of P-Cdc2 (Tyr15), Myt1 and P-Wee1 (Ser642) were upregulated in breast cancer cells, thus suggesting that bakuchiol-induced Cdc2 (Tyr15) phosphorylation may play a central role in $S$ phase arrest in bakuchiol-treated cells. Based on current data that bakuchiol induced the expression of ATM, Chk1 and Chk2, we hypothesized that bakuchiolinduced $S$ phase arrest is sensed by ATM/ATR. ATM/ATR are members of the phosphoinositide 3-kinase-related kinase family that can be activated to phosphorylate on the serine or threonine residues of their substrates in response to DNA damage or replication blocks (Abraham, 2004). ATM/ATR activates Chk1 and Chk2 (Matsuoka et al., 1998), which are known to phosphorylate Cdc25C at Ser216 in response to DNA damage (Bulavin et al., 2003). Cdc25C is a dual-specificity protein kinase that controls mitotic entry by the dephosphorylation of Cdc2 on both Thr14 and Tyr15 (Coleman and Dunphy, 1994). After pre-treating the cells with $5 \mathrm{mM}$ caffeine, a known inhibitor of ATM/ATR kinases, the S phase arrest and increasing expression levels of Chk1 and Chk2 induced by bakuchiol were abrogated, thus suggesting that ATM/ATR, and Chk1/Chk2 as upstream regulators, control bakuchiol-induced Cdc2 (Tyr15) phosphorylation.

In the bakuchiol-induced $S$ phase arrested cells, the p21 expression level was also upregulated. As discussed above, cell entry mitosis depends on the activation of the Cdc2Cyclin B1 complex. It has been shown that p21 blocks the activation of the Cdc2-Cyclin B1 complex by preventing the Thr 161 phosphorylation of the Cdc2 subunit (Smits et al., 2000). The induction of p21 depends on the activation of Chk1/Chk2, and this induction could be found in both p53 -dependent and -independent manner (Kastan and Bartek, 2004; 
Aliouat-Denis et al., 2005). In a negative feedback loop, p21 and p53 can regulate Chk1/Chk2 negatively (Gottifredi et al., 2001; Matsui et al., 2004). Thus, the knock-down of p 21 only marginally rescued the bakuchiol-induced $S$ phase arrest.

Both $E R \alpha$ and $E R \beta$ can regulate upstream regulators of $\mathrm{Cdc} 2$ activation. $\mathrm{ER} \alpha$ downregulates the transcription of ATM via the activation of miRNAs (Guo et al., 2013). ER $\alpha$ also blocks ATR/CHK1 signal transduction cascade through phosphorylation of TopBP1 protein, thus preventing the enhanced association of ATR with TopBP1 after DNA damage (Pedram et al., 2009). Furthermore, ER $\alpha$ inhibits the expression of p21 by up-regulating miR-17 (Liao et al., 2014). ER $\beta$ exhibits opposite effects to ER $\alpha$. Paruthiyil et al. (2004) reported that ER $\beta$ inhibits cell cycle progression by increasing the expression of $\mathrm{p} 21$ in MCF-7 cells. The authors also reported that ER $\beta$ inactivates Cdc2 by inducing it inhibitors, GADD45A and BTG2 (Paruthiyil et al., 2011). Our results show that high doses of bakuchiol suppressed the ER $\alpha$ mRNA levels and induced $\mathrm{ER} \beta$ mRNA levels, suggesting that the ER-mediated inactivation of Cdc2 plays an important role in bakuchiol-induce $S$ phase arrest.

\section{Bakuchiol Induces Apoptosis in MCF-7 Cells via the Intrinsic Mitochondrial Pathway}

$\mathrm{BH} 3$-only proteins-induced activation of Bax/Bak is essential for mitochondrial-mediated apoptosis. Bim is a $\mathrm{BH} 3$-only protein. All the three splice isoforms of Bim (Bim-s, Bim-l, and Bimel) induce apoptosis via binding to $\mathrm{Bcl}-2$ to the mitochondria to relieve the suppression of $\mathrm{Bax} / \mathrm{Bak}$ apoptotic effector oligomerization and pore formation at the outer mitochondrial membranes (O'Connor et al., 1998). Once Bax/Bak is activated, cytochrome $\mathrm{c}$ is released from mitochondria. In the presence of cytochrome $\mathrm{c}$ and dATP, Caspase- 9 and Apaf- 1 bind to each other via their respective $\mathrm{NH} 2$-terminal CED-3 homologous domains, leading to Caspase 9 activation ( $\mathrm{Li}$ et al., 1997). Caspase 9 propagates the death signal by triggering other caspase activation, such as Caspase 7 (Slee et al., 1999). Activation of Caspase 7 leads to the cleavage and inactivation of PARP (Boucher et al., 2012), thus preventing DNA damage repair.

After treatment with bakuchiol, the expression levels of Bim-1, Bim-s, Bax, and Bak were up-regulated. Besides that, Caspase 7, Caspase 9 and PARP were cleaved. The caspase proteases have been shown to play an important role in the

\section{REFERENCES}

Abraham, R. T. (2004). PI 3-kinase related kinases: 'big' players in stressinduced signaling pathways. DNA Repair (Amst.) 3, 883-887. doi: 10.1016/j.dnarep.2004.04.002

Aliouat-Denis, C. M., Dendouga, N., Van den Wyngaert, I., Goehlmann, H., Steller, U., van de Weyer, I., et al. (2005). p53-independent regulation of p21Waf1/Cip1 expression and senescence by Chk2. Mol. Cancer Res. 3, 627634. doi: 10.1158/1541-7786.MCR-05-0121

Bernhard, D., Tinhofer, I., Tonko, M., Hübl, H., Ausserlechner, M. J., Greil, R., et al. (2000). Resveratrol causes arrest in the S-phase prior to Fas-independent apoptosis in CEM-C7H2 acute leukemia cells. Cell Death. Differ. 7, 834-842. doi: $10.1038 /$ sj.cdd. 4400719 accomplishment of apoptotic morphology. They can target proteins which are involved in the formation and regulation of membrane-associated cortical microfilament cytoskeleton (Saraste and Pulkki, 2000). They can also target proteins which are a part of the cell to cell and cell to matrix attachment (Cardone et al., 1997; Wen et al., 1997). Our results suggested that the induction of apoptosis and apoptotic body formation caused by bakuchiol, is likely through intrinsic mitochondrial pathway.

\section{CONCLUSION}

In summary, the present study demonstrated that bakuchiol exhibited both in vitro and in vivo estrogenic activity and anti-breast cancer effect. Bakuchiol exhibited stronger antiproliferative effects in breast cancer cells than its analog resveratrol. Our data showed that bakuchiol induced S phase arrest in breast cancer cells through inactivation of Cdc2. In parallel, apoptosis analysis showed that bakuchiol induced cell apoptosis via the intrinsic mitochondrial pathway. Our results show the potential of bakuchiol as an anti-breast cancer drug, as well as the potential to be used in HRT for relieving menopausal symptoms, but further study is necessary to prove its efficacy and safety.

\section{AUTHOR CONTRIBUTIONS}

LL was involved in the project design, carried out most of the experiments, and drafted the manuscript. XC participated in fish maintenance and exposure. CL helped with the zebrafish xenograft establishment. LSL was involved in optimization of the transfection concentration. CM contributed to the experimental design and manuscript preparation. SC contributed substantially to the experimental design, manuscript preparation and submission. All authors read and approved the final manuscript.

\section{ACKNOWLEDGMENT}

The research was supported by Strategic Research Grant from City University of Hong Kong, Hong Kong, China (Grant No. 7004214).

Boucher, D., Blais, V., and Denault, J. B. (2012). Caspase-7 uses an exosite to promote poly(ADP ribose) polymerase 1 proteolysis. Proc. Natl. Acad. Sci. U.S.A. 109, 5669-5674. doi: 10.1073/pnas.1200934109

Bulavin, D. V., Higashimoto, Y., Demidenko, Z. N., Meek, S., Graves, P., Phillips, C., et al. (2003). Dual phosphorylation controls Cdc25 phosphatases and mitotic entry. Nat. Cell Biol. 5, 545-551. doi: 10.1038/ncb994

Cardone, M. H., Salvesen, G. S., Widmann, C., Johnson, G., and Frisch, S. M. (1997). The regulation of anoikis: MEKK-1 activation requires cleavage by caspases. Cell 90, 315-323. doi: 10.1016/S0092-8674(00) 80339-6

Carter, L. G., D'Orazio, J. A., and Pearson, K. J. (2014). Resveratrol and cancer: focus on in vivo evidence. Endocr. Relat. Cancer 21, R209-R225. doi: 10.1530/erc-13-0171 
Chen, H. L., Feng, H. J., and Li, Y. C. (2010). Vitro antitumor activity and synthesis of the key intermediate of bakuchiol. Yao Xue Xue Bao 45, 467-470.

Chen, X., Kinoshita, M., Hirata, T., Yu, R. M. K., and Cheng, S. H. (2007). Transgenic marine medaka (Oryzias melastigma): a sensitive sentinel for estrogenic pollutants. Mol. Cell Toxicol. 3:34.

Chen, X., Li, V. W., Yu, R. M., and Cheng, S. H. (2008). Choriogenin mRNA as a sensitive molecular biomarker for estrogenic chemicals in developing brackish medaka (Oryzias melastigma). Ecotoxicol. Environ. Saf. 71, 200-208. doi: 10.1016/j.ecoenv.2007.10.005

Chen, Y. J., Chen, Y. Y., Lin, Y. F., Hu, H. Y., and Liao, H. F. (2013). Resveratrol inhibits alpha-melanocyte-stimulating hormone signaling, viability, and invasiveness in melanoma cells. Evid. Based Complement. Alternat. Med. 2013:632121. doi: 10.1155/2013/632121

Chen, Z., Jin, K., Gao, L., Lou, G., Jin, Y., Yu, Y., et al. (2010). Anti-tumor effects of bakuchiol, an analogue of resveratrol, on human lung adenocarcinoma A549 cell line. Eur. J. Pharmacol. 643, 170-179. doi: 10.1016/j.ejphar.2010. 06.025

Choi, S. Y., Lee, S., Choi, W. H., Lee, Y., Jo, Y. O., and Ha, T. Y. (2010). Isolation and anti-inflammatory activity of bakuchiol from Ulmus davidiana var. japonica. J. Med. Food 13, 1019-1023. doi: 10.1089/jmf.2009.1207

Coleman, T. R., and Dunphy, W. G. (1994). Cdc2 regulatory factors. Curr. Opin. Cell Biol. 6, 877-882. doi: 10.1016/0955-0674(94)90060-4

de Kleijn, M. J., van der Schouw, Y. T., Wilson, P. W., Adlercreutz, H., Mazur, W., Grobbee, D. E., et al. (2001). Intake of dietary phytoestrogens is low in postmenopausal women in the United States: the Framingham Study. J. Nutr. 131, 1826-1832.

Gottifredi, V., Karni-Schmidt, O., Shieh, S. S., and Prives, C. (2001). p53 DownRegulates CHK1 through $\mathrm{p} 21$ and the retinoblastoma protein. Mol. Cell. Biol. 21, 1066-1076. doi: 10.1128/MCB.21.4.1066-1076.2001

Guo, X., Yang, C., Qian, X., Lei, T., Li, Y., Shen, H., et al. (2013). Estrogen receptor $\alpha$ regulates ATM expression through miRNAs in breast cancer. Clin. Cancer Res. 19, 4994-5002. doi: 10.1158/1078-0432.CCR-12-3700

Huang, Y., Liu, X., Wu, Y., Li, Y., and Guo, F. (2014). Meroterpenes from Psoralea corylifolia against Pyricularia oryzae. Planta Med. 80, 1298-1303. doi: 10.1055/s-0034-1382995

International Agency for Research on Cancer (2013). International Agency for Research on Cancer. Available at: http://www.iarc.fr/en/media-centre/pr/ 2013/pdfs/pr223_E.pdf (accessed December 12, 2013).

Joe, A. K., Liu, H., Suzui, M., Vural, M. E., Xiao, D., and Weinstein, I. B. (2002). Resveratrol induces growth inhibition, S-phase arrest, apoptosis, and changes in biomarker expression in several human cancer cell lines. Clin. Cancer Res. 8, 893-903.

Kastan, M. B., and Bartek, J. (2004). Cell-cycle checkpoints and cancer. Nature 432, 316-323. doi: 10.1038/nature03097

Key, T. J., Verkasalo, P. K., and Banks, E. (2001). Epidemiology of breast cancer. Lancet Oncol. 2, 133-140. doi: 10.1016/S1470-2045(00)00254-0

Kim, K. A., Shim, S. H., Ahn, H. R., and Jung, S. H. (2013). Protective effects of the compounds isolated from the seed of Psoralea corylifolia on oxidative stress-induced retinal damage. Toxicol. Appl. Pharmacol. 269, 109-120. doi: 10.1016/j.taap.2013.03.017

Li, P., Nijhawan, D., Budihardjo, I., Srinivasula, S. M., Ahmad, M., and Alnemri, E. S. (1997). Cytochrome c and dATP-dependent formation of Apaf-1/caspase- 9 complex initiates an apoptotic protease cascade. Cell 91, 479-489. doi: 10.1016/S0092-8674(00)80434-1

Li, Y. G., Hou, J., Li, S. Y., Lv, X., Ning, J., Wang, P., et al. (2015). Fructus Psoraleae contains natural compounds with potent inhibitory effects towards human carboxylesterase 2. Fitoterapia 101, 99-106. doi: 10.1016/j.fitote.2015. 01.004

Liao, X. H., Lu, D. L., Wang, N., Liu, L. Y., Wang, Y., Li, Y. Q., et al. (2014). Estrogen receptor $\alpha$ mediates proliferation of breast cancer MCF-7 cells via a p21/PCNA/E2F1-dependent pathway. FEBS J. 281, 927-942. doi: $10.1111 /$ febs. 12658

Lim, S. H., Ha, T. Y., Ahn, J., and Kim, S. (2011). Estrogenic activities of Psoralea corylifolia L. seed extracts and main constituents. Phytomedicine 18, 425-430. doi: 10.1016/j.phymed.2011.02.002

Lim, S. H., Ha, T. Y., Kim, S. R., Ahn, J., Park, H. J., and Kim, S. (2009). Ethanol extract of Psoralea corylifolia L. and its main constituent, bakuchiol, reduce bone loss in ovariectomised Sprague-Dawley rats. Br. J. Nutr. 101, 1031-1039. doi: 10.1017/S0007114508066750

Mao, H., Wang, H., Ma, S., Xu, Y., Zhang, H., Wang, Y., et al. (2014). Bidirectional regulation of bakuchiol, an estrogenic-like compound, on catecholamine secretion. Toxicol. Appl. Pharmacol. 274, 180-189. doi: 10.1016/j.taap.2013.11.001

Matsui, T., Katsuno, Y., Inoue, T., Fujita, F., Joh, T., Niida, H., et al. (2004). Negative regulation of Chk2 expression by p53 is dependent on the CCAATbinding transcription factor NF-Y. J. Biol. Chem. 279, 25093-25100. doi: 10.1074/jbc.M403232200

Matsuoka, S., Huang, M., and Elledge, S. J. (1998). Linkage of ATM to cell cycle regulation by the Chk2 protein kinase. Science 282, 1893-1897. doi: $10.1126 /$ science.282.5395.1893

Nehybová, T., Šmarda, J., and Beneš, P. (2014). Plant coumestans: recent advances and future perspectives in cancer therapy. Anticancer Agents Med. Chem. 14, 1351-1362. doi: 10.2174/1871520614666140713172949

O’Connor, L., Strasser, A., O’Reilly, L. A., Hausmann, G., Adam, J. M., Cory, S., et al. (1998). Bim: a novel member of the Bcl-2 family that promotes apoptosis. EMBO J. 17, 384-395. doi: 10.1093/emboj/17.2.384

Oseni, T., Patel, R., Pyle, J., and Jordan, V. C. (2008). Selective estrogen receptor modulators and phytoestrogens. Planta Med. 74, 1656-1665. doi: 10.1055/s0028-1088304

Paruthiyil, S., Cvoro, A., Tagliaferri, M., Cohen, I., Shtivelman, E., and Leitman, D. C. (2011). Estrogen receptor $\beta$ causes a G2 cell cycle arrest by inhibiting CDK1 activity through the regulation of cyclin B1, GADD45A, and BTG2. Breast Cancer Res. Treat. 129, 777-784. doi: 10.1007/s10549-0101273-5

Paruthiyil, S., Parmar, H., Kerekatte, V., Cunha, G. R., Firestone, G. L., and Leitman, D. C. (2004). Estrogen receptor beta inhibits human breast cancer cell proliferation and tumor formation by causing a G2 cell cycle arrest. Cancer Res. 64, 423-428. doi: 10.1158/0008-5472.CAN-03-2446

Patisaul, H. B., and Jefferson, W. (2010). The pros and cons of phytoestrogens. Front. Neuroendocrinol. 31:400-419. doi: 10.1016/j.yfrne.2010.03.003

Pedram, A., Razandi, M., Evinger, A. J., Lee, E., and Levin, E. R. (2009). Estrogen inhibits ATR signaling to cell cycle checkpoints and DNA repair. Mol. Biol. Cell 20, 3374-3389. doi: 10.1091/mbc.E09-01-0085

Pianjing, P., Thiantanawat, A., Rangkadilok, N., Watcharasit, P., Mahidol, C., and Satayavivad, J. (2011). Estrogenic activities of sesame lignans and their metabolites on human breast cancer cells. J. Agric. Food Chem. 59, 212-221. doi: 10.1021/jf102006w

Rice, S., and Whitehead, S. A. (2006). Phytoestrogens and breast cancer-promoters or protectors? Endocr. Relat. Cancer 13, 995-1015. doi: 10.1677/erc.1.01159

Saraste, A., and Pulkki, K. (2000). Morphologic and biochemical hallmarks of apoptosis. Cardiovasc. Res. 45, 528-537. doi: 10.1016/S0008-6363(99) 00384-3

Setchell, K. D. (2001). Soy isoflavones-benefits and risks from nature's selective estrogen receptor modulators (SERMs). J. Am. Coll. Nutr. 20(Suppl. 5), 354S-362S; discussion 381S-383S. doi: 10.1080/07315724.2001.107 19168

Shou, Q. Y., Yang, R. P., Wang, B. H., Liu, J. Y., and Xu, J. H. (2007). Study on the effective constituents with estrogenic action in Fructus Psoraleae. Tradit Chin. Drugs Res. Clin. Pharmacol. 18, 425-427.

Slee, E. A., Harte, M. T., Kluck, R. M., Wolf, B. B., Casiano, C. A., Newmeyer, D. D., et al. (1999). Ordering the cytochrome c-initiated caspase cascade: hierarchical activation of caspases- $2,-3,-6,-7,-8$, and -10 in a caspase-9-dependent manner. J. Cell Biol. 144, 281-292. doi: 10.1083/jcb.144.2.281

Smits, V. A., Klompmaker, R., Vallenius, T., Rijksen, G., Mäkela, T. P., and Medema, R. H. (2000). p21 inhibits Thr161 phosphorylation of Cdc2 to enforce the G2 DNA damage checkpoint. J. Biol. Chem. 275, 30638-30643. doi: 10.1074/jbc.M005437200

Tyagi, A., Singh, R. P., Agarwal, C., Siriwardana, S., Sclafani, R. A., and Agarwal, R. (2005). Resveratrol causes Cdc2-tyr15 phosphorylation via ATM/ATR-Chk1/2-Cdc25C pathway as a central mechanism for S phase arrest in human ovarian carcinoma Ovcar-3 cells. Carcinogenesis 26, 1978-1987. doi: 10.1093/carcin/bgi165

Wen, L. P., Fahrni, J. A., Troie, S., Guan, J. L., Orth, K., and Rosen, G. D. (1997). Cleavage of focal adhesion kinase by caspases during apoptosis. J. Biol. Chem. 272, 26056-26061. doi: 10.1074/jbc.272.41.26056 
Xin, D., Wang, H., Yang, J., Su, Y. F., Fan, G. W., Wang, Y. F., et al. (2010). Phytoestrogens from Psoralea corylifolia reveal estrogen receptor subtype selectivity. Phytomedicine 17, 126-131. doi: 10.1016/j.phymed.2009. 05.015

Yu, Y. C., Yang, P. M., Chuah, Q. Y., Huang, Y. H., Peng, C. W., Lee, Y. J., et al. (2013). Radiation-induced senescence in securin-deficient cancer cells promoted cell invasion involving the IL-6/STAT3 and PDGF-BB/PDGFR pathways. Sci. Rep. 3:1675. doi: 10.1038/srep01675

Zhou, B. B., and Elledge, S. J. (2000). The DNA damage response: putting checkpoints in perspective. Nature 408, 433-439. doi: 10.1038/35044005
Conflict of Interest Statement: The authors declare that the research was conducted in the absence of any commercial or financial relationships that could be construed as a potential conflict of interest.

Copyright (c) $2016 \mathrm{Li}$, Chen, Liu, Lee, Man and Cheng. This is an open-access article distributed under the terms of the Creative Commons Attribution License (CC BY). The use, distribution or reproduction in other forums is permitted, provided the original author(s) or licensor are credited and that the original publication in this journal is cited, in accordance with accepted academic practice. No use, distribution or reproduction is permitted which does not comply with these terms. 